\title{
Sequestering a non-steroidal anti-inflammatory drug using modified orange peels
}

\author{
Olugbenga Solomon Bello ${ }^{1,3}$ [ Temitope Chris Alagbada ${ }^{1}$. Oluwakemi Christiana Alao' \\ Abimbola Modupe Olatunde ${ }^{2}$
}

Received: 13 March 2019 / Accepted: 11 June 2020 / Published online: 26 June 2020

(C) The Author(s) 2020

\begin{abstract}
This study investigates the sorption of a non-steroidal anti-inflammatory drug, ibuprofen, (IBP) using acid activated carbon prepared from orange peel (OPA). OPA was characterized via the use of Fourier transform infrared and scanning electron microscopy techniques. Four isotherm models were utilized to assess the adsorption data: Langmuir, Freundlich, Temkin, and DubininRaduskevich, respectively. It was established that the IBP adsorption onto OPA fitted Langmuir isotherm model most. The optimum monolayer adsorption capacity of OPA was $49.30 \mathrm{mg} / \mathrm{g}$ at $50^{\circ} \mathrm{C}$. The adsorption data was subjected to kinetic test using pseudo-first-order and pseudo-second-order, Elovich, and intraparticle diffusion models. The sorption process was best described by pseudo-second-order kinetic model. The mean heat of adsorption, $E_{a}$ at all temperatures studied was $<8.00 \mathrm{kJmol}^{-1}$, signifying that the sorption mechanism is physisorption. Thermodynamic study reveals that the adsorption is spontaneous and exothermic. OPA was established to be a viable and effective adsorbent for the sorption of IBP from aqueous medium.
\end{abstract}

Keywords Adsorption · Orange peel · Ibuprofen $\cdot$ Kinetics $\cdot$ Thermodynamics

\section{Introduction}

Endocrine-disrupting chemicals (EDCs) are bioactive compounds that affect living tissues. According to the report of the Environmental Protection Agency of 2015, an endocrine disruptive chemical is a substance which affects the production, secretion, binding, movement, function and/or

Olugbenga Solomon Bello

osbello06@gmail.com; osbello@lautech.edu.ng

Temitope Chris Alagbada

tcalagbada@student.lautech.edu.ng

Oluwakemi Christiana Alao

ocalao@student.lautech.edu.ng

Abimbola Modupe Olatunde

am.olatunde@ui.edu.ng

1 Department of Pure and Applied Chemistry, Ladoke Akintola University of Technology, P.M.B. 4000, Ogbomoso, Oyo State, Nigeria

2 Department of Chemistry, University of Ibadan, Ibadan, Oyo State, Nigeria

3 Department of Physical Sciences, Industrial Chemistry Programme, Landmark University, P.M.B. 1001, Omu-Aran, Kwara State, Nigeria removal of some natural hormones which are accountable for the upkeep of homeostasis, behavior, reproduction, and growth within the body (Diamanti-Kandarakis et al. 2009; Endocrine Society 2016). The endocrine system comprises of an assembly of glands which secrete hormones into the circulatory system and transports them to specific organs in the body. The major function of hormones in animals is the coordination of chemicals (Hafez et al. 2016). This helps in the regulation of various body functions such as growth, sexual development and reproduction. EDCs can imitate some hormones that occur naturally in the body, according to the National Institute of Environmental Health Sciences, EDC binds to a receptor within the cell, and then interfere with the hormonal secretion or control of the receptor. Abnormalities and reduction in organ activities are some of the resulting effects of such disruptions. The everyday use of chemicals in foods and other daily needs such as soaps, perfumes, and other household products, which has become a norm in the modern society, has brought about the release of persistent substances, many of which introduce EDCs into the surroundings. Available data has confirmed the high risk that these EDCs pose on human metabolism which can eventually lead to metabolic diseases (Swedenborg et al. 2009; Propper 2005). Parabens are examples of antimicrobial 
<smiles>CC(C)Cc1ccc(C(C)C(=O)O)cc1</smiles>

Fig. 1 Structure of ibuprofen

Table 1 Physiochemical properties of ibuprofen

\begin{tabular}{ll}
\hline Appearance & Colourless crystalline solid \\
\hline Boiling point & $157{ }^{\circ} \mathrm{C}$ \\
Brand name & Brufen; Motrin; Nurofen; Advil; Nuprin \\
Density & $1.029 \mathrm{~g} / \mathrm{cm}^{3}$ \\
IUPAC name & (RS)-2-(4-(2-Methylpropyl)phenyl)propanoic \\
& acid \\
Melting point & $77-78{ }^{\circ} \mathrm{C}$ \\
Molar mass & $206.28 \mathrm{~g} / \mathrm{mol}$ \\
Molecular formula & $\mathrm{C}_{13} \mathrm{H}_{18} \mathrm{O}_{2}$ \\
Solubility & Partially soluble in water but soluble in organic \\
& solvent \\
\hline
\end{tabular}

agents that have weak estrogenic activity and are in most cosmetics and food materials (Daughton and Ternes 1999). In this study, ibuprofen is of primary concern as a form of EDC in the environment. The consumption rate of ibuprofen in the world is very high. For example, in UK, it is one of the most highly rated (among top five) consumed drugs, with annual estimation production of several kilotons (Sebastine and Wakeman 2003; National Institute of Environmental Health Sciences 2019).

Ibuprofen is among the important drugs enumerated by the World Health Organization, and so ibuprofen is among the common pharmaceuticals regularly found within reach (National Institute of Environmental Health Sciences 2019). Figure 1 represents ibuprofen structure with a molecular formula of $\mathrm{C}_{13} \mathrm{H}_{18} \mathrm{O}_{2}$, having an IUPAC nomenclature of 2-\{4-(2-methylpropyl) phenyl $\}$ propanoic acid. It was initially developed in the year 1960 while investigating for a safer substitute for aspirin. A non-steroidal anti-inflammatory drug (NSAID) is use to suppress pain, fever, arthritis symptoms, and dysmenorrhea. It is identified to possess an antiplatelet effect. Comparison with aspirin or some wellknown antiplatelet drugs indicate that it is comparatively mild and short-lived. It acts as vasodilator, having been revealed to enlarge coronary arteries and some other blood vessels. A small dose of ibuprofen is healthy but large dose is usually accompanied by health hazard. The physiochemical properties of ibuprofen are shown in Table.1.

In the world, several kilotons of ibuprofen are produced yearly (Buser et al. 1999) and effluents from pharmaceutical industries producing ibuprofen are released into the environment without adequate treatment. It was stated that the quantity of IBP in the surroundings falls within the range of $10 \mu \mathrm{g} / \mathrm{L}$ and $169 \mu \mathrm{g} / \mathrm{L}$ (Dos Santos et al. 2007). The endocrine disruptive action of IBP has been identified through various studies (Buser et al. 1999). "4-IBAP (4- isobutylacetophenone)" is one of the harmful metabolites of ibuprofen which is known for its hazardous effect on the CNS (central nervous system). Hence, it is of necessity to develop an effective means for sequestering IBP from the environment.

There are different techniques for the uptake of EDCs from wastewater; these include: membrane filtration (Zhang et al. 2014), oxidation processes (Garoma and Matsumoto 2009), ultrasonic treatment (Méndez-Arriaga et al. 2008), electrochemical degrading (Ciriaco et al. 2009), miniature created wetlands (Dordio et al. 2009, 2010), and adsorption (Choi et al. 2005). Among the various clean-up methods available, adsorption method with activated carbon is the most sustainable because it is eco-friendly and is mostly used for EDC removal. Different agricultural wastes materials have been used as adsorbents, among them are: hen feathers (Gupta et al. 2006), wheat husks (Gupta et al. 2007), bottom ash and deoiled soya (Gupta et al. 2009), durian seed (Ahmad et al. 2014a and b), lime peels (Ahmad et al. 2015), banana stalk (Bello et al. 2012).

However, commercially activated carbon is costly and scarce; hence there is a need to investigate the effectiveness of different agricultural wastes or natural substances in removing IBP from industrial effluents.

The most extensively used adsorbents for emerging contaminants adsorption from effluent is activated carbon; this is as a result of their enlarged surface area, high porosity, high level of surface reactivity, high capacity of adsorption and its efficiency in removing a wide range of different forms of adsorbates (Nasuha et al. 2010). Orange peels are usually found in large quantity in soft drinks industries and usually treated as wastes thereby serving as pollutants to the environment. Its component includes: cellulose, pectin, chlorophyll pigments, lignin, hemicellulose and other hydrocarbons with relative low molecular weight. Based on our findings, there is no documented report addressing the use of orange peel activated carbon (OPA) for the adsorption of IBP from wastewater. This research work is focused on the preparation and characterization of orange peel as an activated carbon for the purpose of adsorbing IBP from aqueous media. Effect of operational parameters includes: Contact time, temperature, and initial concentration governing the adsorption were studied. Sorption Isotherm, kinetic and thermodynamic studies were carried out. 


\section{Materials and methods}

\section{Sample collection and pre-treatment}

Orange peel samples were collected from a disposal unit at LAUTECH Ogbomoso where they serve as agricultural wastes. It undergoes washing using distilled water followed by drying to a specific weight. It was later crushed into smaller particles and sieved to $106 \mu \mathrm{m}$ size. Thereafter, it was stored in a desiccator for further use.

\section{Adsorbent characterization}

\section{Fourier transform infrared (FTIR)}

FTIR spectroscopic study of orange peel was carried-out using FTIR spectroscopy device (FTIR-2000, Perkin Elmer). This equipment gave spectra revealing the typical functional groups present in both the raw and acid activated orange peel samples.

\section{Scanning electron micrograph}

This microscope (SEM) is among the most versatile device used in determining and investigating morphological structures. This equipment was utilized to investigate the porosity level and surface properties of both raw and acid activated orange peel samples. The sample with numerous pores has high affinity for adsorption of adsorbates.

\section{Activated carbon preparation}

Thirty grams of orange peel sample was measured into a beaker followed by the addition of $600 \mathrm{~cm}^{3}$ of $\mathrm{H}_{3} \mathrm{PO}_{4}$; it was continuously stirred on a hot plate using a stirrer until the formation of a paste. This was moved into a crucible and then subjected to heating at $500{ }^{\circ} \mathrm{C}$ for $1 \mathrm{~h} 30 \mathrm{~min}$ in a furnace. It undergoes cooling followed by washing using de-ionized water until a $\mathrm{pH}$ of 6.9 was achieved. It was dried at a temperature of $105{ }^{\circ} \mathrm{C}$ for $4 \mathrm{~h}$ in an oven. Thereafter, it was crushed to smaller size. The adsorbent was stored in desiccator for further use.

\section{Adsorbate solution preparation}

Preparation of the stock solution was done by dissolving ibuprofen $(500 \mathrm{mg})$ in $1 \mathrm{~L}$ of ethanol. Working solutions were obtained by serial dilution from the stock solution. Ibuprofen is moderately water soluble (Baccar et al. 2012); however, it is completely soluble in organic solvents
(Manrique and Martinez 2007). Due to this, ethanol (organic solvent) was used as a solvent for the adsorbate so as to ensure complete dissolution.

\section{Adsorption equilibrium experiments}

Ten milligrams of the adsorbent was weighed into prearranged conical flasks $(250 \mathrm{ml})$ which contains $100 \mathrm{ml}$ solutions of IBP with various initial IBP concentrations $(5-25 \mathrm{mg} / \mathrm{L})$. This mixture was then agitated using isothermal water bath at 120 revolutions per minute at different temperatures $\left(30,40,50{ }^{\circ} \mathrm{C}\right)$ until equilibrium was reached. The solution of the sample was taken at pre-determined time intervals using micro filter syringe for residual concentration determination. Concentrations of IBP solutions were obtained by taking the absorbance readings using UV-Vis spectrophotometer at $240 \mathrm{~nm}$ wavelength. Solution temperature, initial IBP concentration and contact time of the process were also examined. The amount of IBP adsorbed and the percentage removed were determined using the equation below:

$q_{e}=\frac{\left(C_{e}-C_{o}\right)}{W}$

where $C_{o}$ signifies IBP initial concentrations at liquid-phase. $C_{e}$ signifies equilibrium concentrations of IBP at liquidphase measured in $\left(\mathrm{mgL}^{-1}\right) . V$ signifies volume $\left(\mathrm{dm}^{3}\right) . W$ signifies adsorbent mass used $(g)$. Percentage uptake of IBP was calculated using Eq. 2.

$\operatorname{Removal}(\%) \frac{\left(C_{e}-C_{o}\right)}{C_{o}} \times 100$

where $C_{0}$ signifies initial concentration of IBP at liquidphase $\left(\mathrm{mgL}^{-1}\right), C_{e}$ signifies equilibrium. concentration of Ibuprofen $\left(\mathrm{mgL}^{-1}\right)$.

\section{Solution temperature effect}

The influence of solution temperature on the IBP sorption process was observed at different temperatures: $30^{\circ} \mathrm{C}$, $40{ }^{\circ} \mathrm{C}$ and $50{ }^{\circ} \mathrm{C}$, respectively. This was done by adjusting the temperature regulator of the water bath shaker.

\section{Adsorption isotherms}

This allows us to determine the process of adsorption at equilibrium point of adsorption. Four models were employed to test the adsorption data. 


\section{Langmuir isotherm}

This is centered on a single layer and uniform adsorption to the surface of a solid. Langmuir suggested that the distance is inversely proportional to the intermolecular forces, in accordance with Langmuir (Eq. 3).

$\frac{C_{e}}{q_{e}}=\frac{C_{e}}{q_{m}}+\frac{1}{K_{L} q_{m}}$

$C_{e}=$ adsorbate concentration at equilibrium $\left(\mathrm{mgL}^{-1}\right)$; $q_{e}=$ adsorbate concentration uptake per unit weight of adsorbent $(\mathrm{mg} / \mathrm{g}) ; q_{m}=$ Adsorbent optimum adsorptive capacity (mg/g); $K_{L}=$ Langmuir constant (L/mg). Langmuir constant is obtained from the graph of $\frac{c_{e}}{q_{e}}$ against $C_{e}$. The features of Langmuir expression may be expressed in form of $R_{L}$ (separator factor) that has no dimension which is expressed as:

$R_{L}=\frac{1}{\left(1+K_{L} C_{o}\right)}$

$C_{o}$ signifies the maximum initial amount of solute. The dimensionless constant $\left(R_{L}\right)$ signifies that the sorption is satisfactory $\left(0<R_{L}<1\right)$, unsatisfactory $\left(R_{L}>1\right)$, linear $\left(R_{L}=1\right)$, or irreversible $\left(R_{L}=0\right)$.

\section{Freundlich isotherm}

This describes sorption process which occurs on nonuniform surface. It suggests that the spots whose binding strength is higher are first occupied and reduction in the strength depends on the filling rate of the sites. The Freundlich isotherm (Freundlich 1906) is:

$\ln q_{e}=\ln k_{f}+\frac{1}{n} \ln C_{e}$

where $q_{e}$ signifies adsorbate concentration uptake per unit weight of adsorbent $(\mathrm{mg} / \mathrm{g}) ; k_{f}$ signifies Freundlich constant $\left(\mathrm{mgg}^{-1}\right)$, which specify the comparative adsorption capacity of the adsorbent associated with binding energy; $C_{e}$ signifies adsorbate equilibrium concentration $(\mathrm{mg} / \mathrm{L}) ; \mathrm{n}$ signifies Freundlich coefficient signifying the deviance from adsorption linearity and is also referred to as heterogeneity factor.

\section{Temkin isotherm}

This accounts for the effect of the interaction which exists between the adsorbate and the adsorbent. This isotherm predicts that the heat of adsorption for all molecules in the film is inversely proportional to the coverage surface. This model is expressed below (Temkin and Pyzhev 1940):

$q_{e}=B \ln K_{t}+B \ln C_{e}$ where

$B=\frac{R T}{b}$

$B$ signifies heat capacity constant $\left(\mathrm{Lmg}^{-1}\right) ; b$ signifies Temkin constant; $q_{e}$ signifies adsorbate concentration uptake at equilibrium $(\mathrm{mg} / \mathrm{g}) ; C_{e}$ signifies amount of adsorbate at equilibrium $\left(\mathrm{mgL}^{-1}\right) ; T$ signifies Temperature; $R$ signifies Gas constant $(8.314 \mathrm{~J} / \mathrm{mol} \mathrm{K}) ; K_{t}$ signifies Equilibrium binding constant $(\mathrm{L} / \mathrm{mg})$. The plots of $q_{e}$ against $C_{e}$ give a straight line graph.

\section{Dubinin-Radushkevich isotherm}

This isotherm accounts for the free energy of adsorption and porosity. It is used in describing the mechanism of adsorption with Gaussian dispersion energy to a uniform surface. It is stated as (Dubinin and Radushkevich 1947):

$\ln q_{e}=\ln q_{m}-\beta \varepsilon^{2}$

where $\varepsilon$ can be estimated from

$\varepsilon=\mathrm{RT}\left[1+\frac{1}{c_{e}}\right]$

$E_{a}=\frac{1}{\sqrt{2 \beta}}$

where $R$ signifies gas constant $(8.314 \mathrm{~J} / \mathrm{mol} / \mathrm{K}), T$ signifies temperature $(K), C_{e}$ signifies amount of adsorbate at equilibrium $\left(\mathrm{mgL}^{-1}\right) . E$ signifies free energy of adsorption.

\section{Adsorption kinetic studies}

It portrays the interaction that exists between the amount of adsorbate in the solution and adsorption rate, and the effect of adsorption capacity in terms of adsorption rate. In this study, four models were engaged to test the adsorption data. These includes: pseudo first-order (Lagergren and Svenska 1898), pseudo-second-order, (Ho and McKay 1999a, b) Elovich (Unganish et al. 1976), and intraparticle diffusion (Weber and Morris 1962), respectively.

\section{Kinetic study validation}

Standard deviation $\Delta q_{e}(\%)$ were employed to authenticate the kinetic models used in testing the adsorption data. The isotherm expression suitability toward the adsorption kinetic data was ascertained via comparing the $R^{2}$ values.

$\Delta q_{e}(\%)=100 \frac{\sqrt{\left(q_{e \cdot \exp }-q_{e . \mathrm{cal}}\right)}}{N-1}$ 
$N$ denotes the number of data points, $q_{e \text { exp }}$ denotes the experimental value $(\mathrm{mg} / \mathrm{g})$ and $q_{e \text {.cal }}$ denotes the calculated value $\left(\mathrm{mg} \cdot \mathrm{g}^{-1}\right)$.

\section{Test of kinetic models}

These models were subjected to validation using the sum of squares error (SSE \%) aside from the $R^{2}$ value. The kinetic adsorption process of IBP onto orange peel activated carbon was investigated at different initial concentrations. The sum of squares error (SSE, \%) is expressed as:

$\operatorname{SSE}(\%)=\sqrt{\sum \frac{\left(q_{e \cdot \exp }-q_{e . \mathrm{calc}}\right)^{2}}{N}}$

$N$ denotes the number of data points, $q_{e \text { exp }}$ denotes the experimental value $\left(\mathrm{mg} . \mathrm{g}^{-1}\right)$ and $q_{e \text {.cal }}$ denotes the estimated value $\left(\mathrm{mg} \mathrm{g}^{-1}\right)$. A low value of SSE signifies good fit.

\section{Adsorption thermodynamic studies}

This study was examined as a function of temperature. Its parameters are $\Delta G^{\circ}, \Delta H^{\circ}$ and $\Delta S^{\circ}$, which are essential in defining the spontaneity and the nature of the relationship that exist between the adsorbent and adsorbate. It was determined employing the following equations:

$\operatorname{In} K_{L}=\frac{\Delta S^{\circ}}{R}-\frac{\Delta H^{\circ}}{\mathrm{RT}}$

where $K_{L}$ represents Langmuir constant (g/L) $\Delta S^{\circ}$ represents entropy change $(\mathrm{kJ} / \mathrm{mol} \mathrm{K}) . R$ represents gas constant $(\mathrm{J} /$ mol K). $\Delta H^{\circ}$ represents enthalpy change $(\mathrm{kJ} / \mathrm{mol}) . T$ represents the temperature $(K)$. Therefore, $\Delta H^{\circ}$ and $\Delta S^{\circ}$ were gotten from a plot of $\ln K_{L}$ against $1 / \mathrm{T}$. If $\Delta \mathrm{H}^{\circ}$ value is positive, it depicts an endothermic adsorption exercise; meanwhile, if the value is negative, it shows that the process is exothermic. A nonnegative value of $\Delta S^{\circ}$ implies a rise in the level of disorderliness at the solution/solid interface which takes place in the course of the adsorption (Bello et al. 2011). In addition, when the value of $\Delta G^{\circ}$ is negative, it reveals that the sorption is spontaneous at the studied temperature. $\Delta G^{\circ}$ can be estimated via the expression below:

$\Delta G^{\circ}=-\mathrm{RTIn} K_{o}$

Arrhenius expression was used to ascertain whether the adsorption is chemical or physical in nature. Physisorption process has $E_{a}$ which falls within 5 to $40 \mathrm{~kJ} / \mathrm{mol}$. Nollet et al. (2003), documented that chemisorption processes possess elevated energy of activation that falls within $40-800 \mathrm{~kJ} /$ mol.

\section{Results and discussion}

\section{Characterization}

\section{Scanning electron microscopy (SEM)}

This equipment was employed to detect the pore size distribution of the adsorbent. Figure $2 \mathrm{a}$ and $\mathrm{b}$ respectively depicts the SEM of OPR and OPAC as shown below. Comparing these figures, OPR has a rough surface with undeveloped pore size, but for OPAC, well-enlarged pores were formed on the surface. This implies that the activation process was effective in opening up the pores of the adsorbent. OPAC has several pore sizes for the uptake of ibuprofen drug molecules. Similar observations were observed in other reported
Fig. 2 a The micrograph of OPR. b The micrograph of OPA

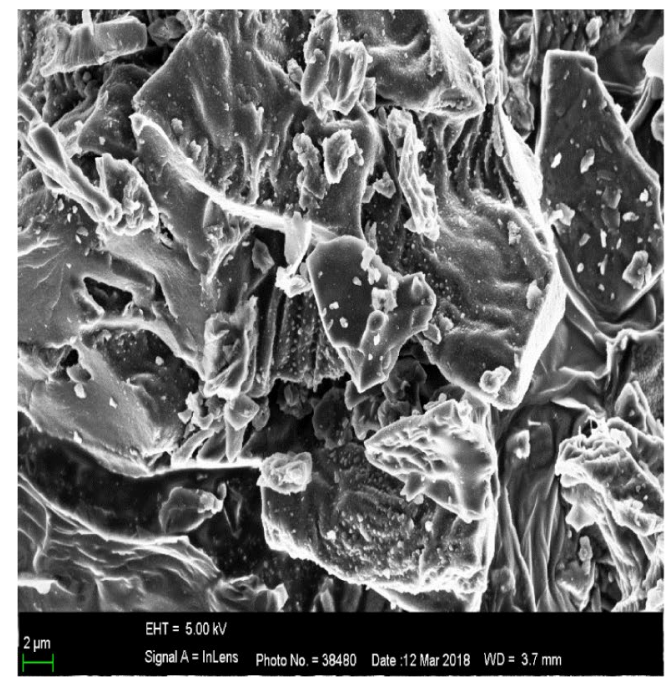

(a) The micrograph of OPR

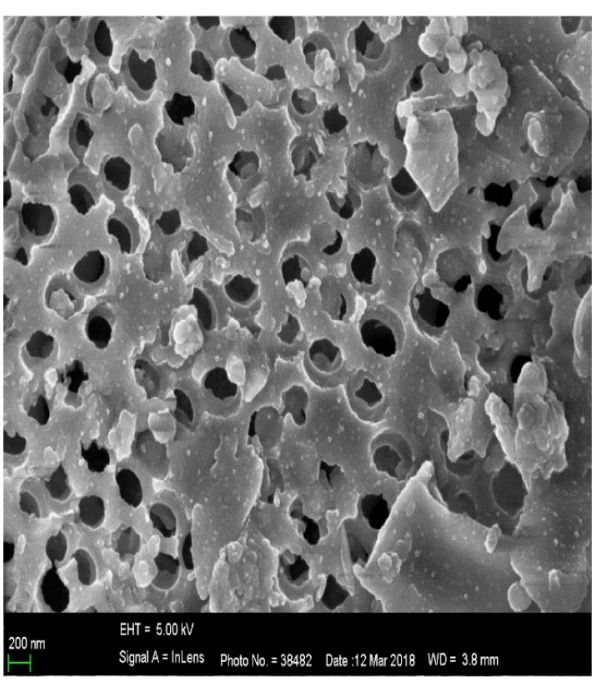

(b) The micrograph of OPA

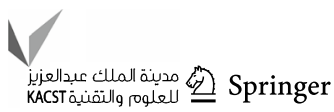


studies (Bui and Choi 2009; Shashi et al. 2010; Ahmad et al. 2014a and b).

\section{Fourier transform infrared spectroscopy (FTIR)}

This technique revealed the functional groups available in the adsorbent. The samples were studied within $400-4000 \mathrm{~cm}^{-1}$ on an FTIR spectrophotometer using $\mathrm{KBr}$ discs. The FTIR spectra of orange peel raw (OPR) and activated orange peel (OPAC) are shown below (Fig. 3a and $\mathrm{b}$ respectively). From these figures, some broad peaks are observed while some bands are shifted to lower and higher wavenumbers. New peaks are also formed as a result of activation process. Table 2 contains the FTIR band assignment of OPAC. A similar band assignment was observed from the studies carried out by Ahmad et al. (2015) and Bello et al. (2012).

\section{Batch adsorption studies}

\section{Adsorption isotherms}

Isotherm models investigated include: Langmuir, Freundlich, Temkin, and Dubinin-Radushkevich. The isotherm having the highest correlation coefficient $\left(R^{2}\right)$ value fit the adsorption data most. Langmuir theory (Langmuir 1918) suggests that the sorbent surface is homogeneous, and there is no interaction in-between the molecules adsorbed during the formation of a monolayer surface coverage. Table 3 shows the different isotherm parameters calculated at various temperatures. From Table 4, the highest value of $q_{m}$ is $49.3 \mathrm{mg} / \mathrm{g}$ at $50{ }^{\circ} \mathrm{C}$ Comparing this value (maximum monolayer adsorption capacities of OPAC) with other adsorbent shows that OPAC is an effective adsorbent (Table 4). The $R_{L}$ value calculated at various temperatures range from $0.0039-0.140$. The values are less than 1, suggesting that the adsorption data was favorable at all IBP concentration range studied (Zhang and Pan 2014).

This model can be used when the adsorption surface is not uniform, and the extent of adsorption increases with concentration (Mittal et al. 2008). The values of $n$ for Freundlich isotherm were all greater than 1 , signifying that the adsorption process was favorable for IBP adsorption on OPAC. The $1 / n$ values were below 1 at all temperatures, indicating that the adsorbate was favorably adsorbed on the adsorbent (Tunç et al. 2009). The Freundlich constant $\left(k_{F}\right)$ at $323 \mathrm{~K}$ is 59.9, which is approximately three times greater when compared with that of $303 \mathrm{~K}\left(k_{F}=20.3\right)$. This suggests that a rise in temperature increases the adsorbent sorption capacity. D-R and Langmuir isotherms fit the adsorption data most, judging from $\mathrm{R}^{2}$ values, these signify that the surface binding energy of the adsorbent was homogeneous, the relationship between the adsorbent and adsorbate was negligible, and no competition exists between the molecules of IBP adsorbed on the surface of the adsorbent (Gong et al. 2008).

Temkin isotherm constant $\left(b_{T}\right)$ otherwise known as the equilibrium binding factor was calculated from the Temkin isotherm expression. As shown in Table 3, OPAC has the highest equilibrium binding constant at low temperature. The apparent free energy (E), porosity, and the sorption process parameters were investigated using Dubinin-Radushkevich isotherm model. The value of $E_{a}$ at various working temperatures lies in the range 5.00-7.07 kJ/mol. Since $\mathrm{E}_{\mathrm{a}}<40 \mathrm{~kJ} / \mathrm{mol}$, the nature of adsorption mechanism is physisorption (Onyango et al. 2004). Comparing the average correlation coefficient $\left(R^{2}\right)$, it was inferred that the adsorption data fits the isotherm in this order: Dubinin-Radushkevich $\left(R^{2}=0.965\right)>$ Langmuir $\left(R^{2}=0.960\right)>$ Freundlich $\left(R^{2}=0.954\right)>$ Temkin $\left(R^{2}=0.953\right)$. Generally, Langmuir adsorption isotherm is based on single layer coverage of the IBP on the adsorbent surface which depict that the adsorption of IBP by activated carbon follows monolayer formation (Singh et al. 2012).

\section{Separation factor}

Langmuir expression may be expressed in form of separation factor, $R_{L}$. The $R_{L}$ value depict the favorability of adsorption; it can be interpreted in this wise; adsorption is irreversible when $\left(R_{L}=0\right)$, adsorption is favorable when $\left(0<R_{L}<1\right)$ and adsorption is linear when $\left(R_{L}=1\right)$. It was observed in Table 3 that, the values of $R_{L}$ ranges from 0 to 1 for the adsorption of IBP onto OPAC. This reveals that the adsorption process was favorable at the temperature range studied (Bello et al. 2011).

\section{Adsorption kinetic studies}

The kinetic data for IBP adsorption onto OPAC are presented in Table 5. To determine the most suitable kinetic model, correlation coefficient $\left(R^{2}\right)$ values were computed. $R^{2}$ values of pseudo-first-order kinetic model ranged from 0.8848 to 0.9347 . These values are lower when compared to that of pseudo-second-order kinetic model i.e. 0.999 to 1 (Table 5) suggesting that pseudo-second-order best fit the adsorption data. Similarly, Fig. 4 shows the plot of $t / q_{t}$ versus $t$ for pseudo-second-order model. The plot gave straight line which passes through the origin; this is an indication of a good fit. Also, considering $R^{2}$ values and the relationship between $q_{e, \text { cal. }}$ and $q_{e, \text { exp. calculated from the adsorption }}$ data, there were good agreements in the values obtained for pseudo-second-order kinetic model. This denotes that pseudo-second-order kinetic model fits the adsorption data most. The kinetic data of uptake of IBP by OPAC at different initial concentrations were subjected to model validity test using sum squares of error (SSE, \%) A low value of SSE 


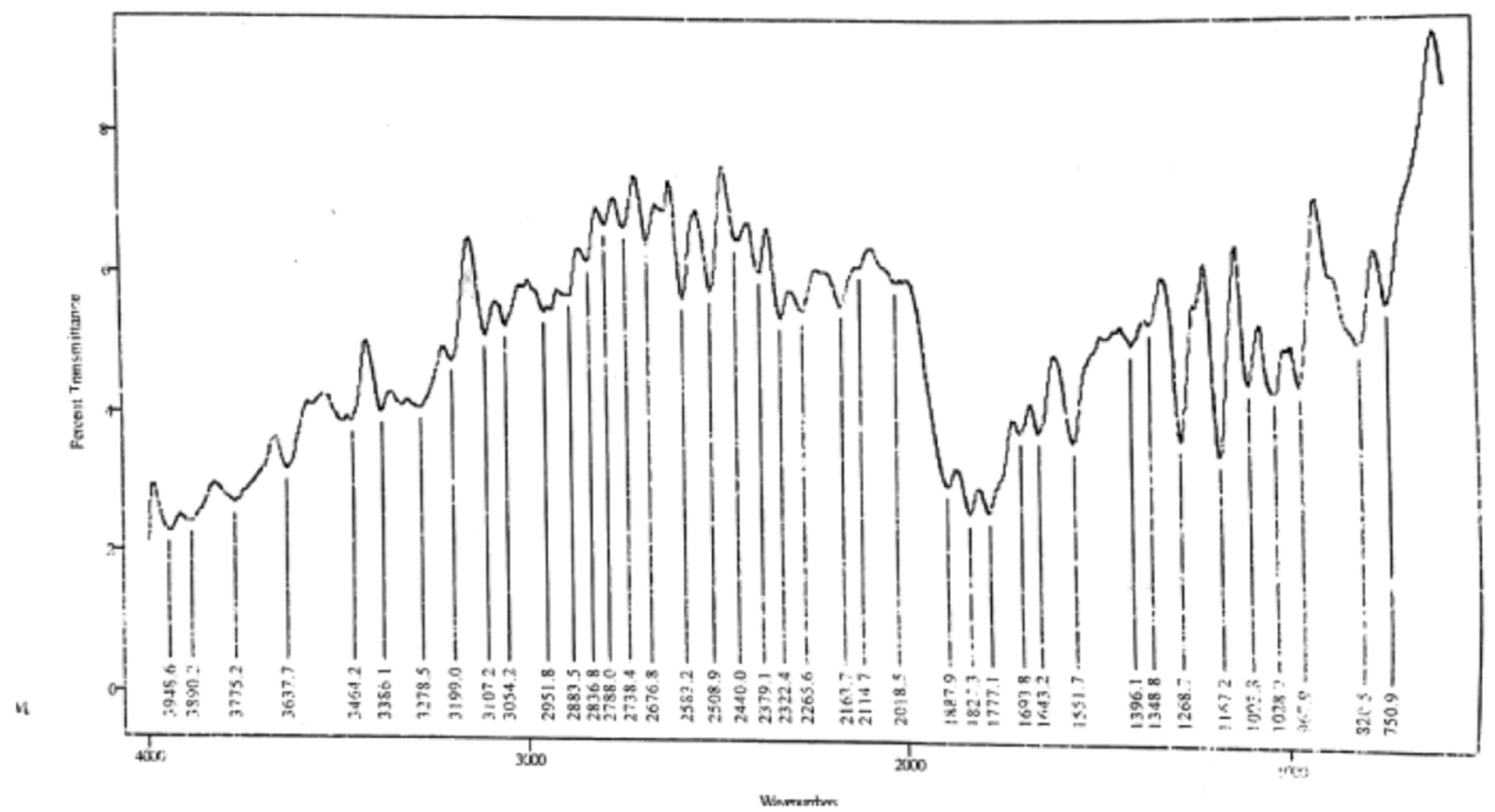

(a) FTIR Spectrum of OPR

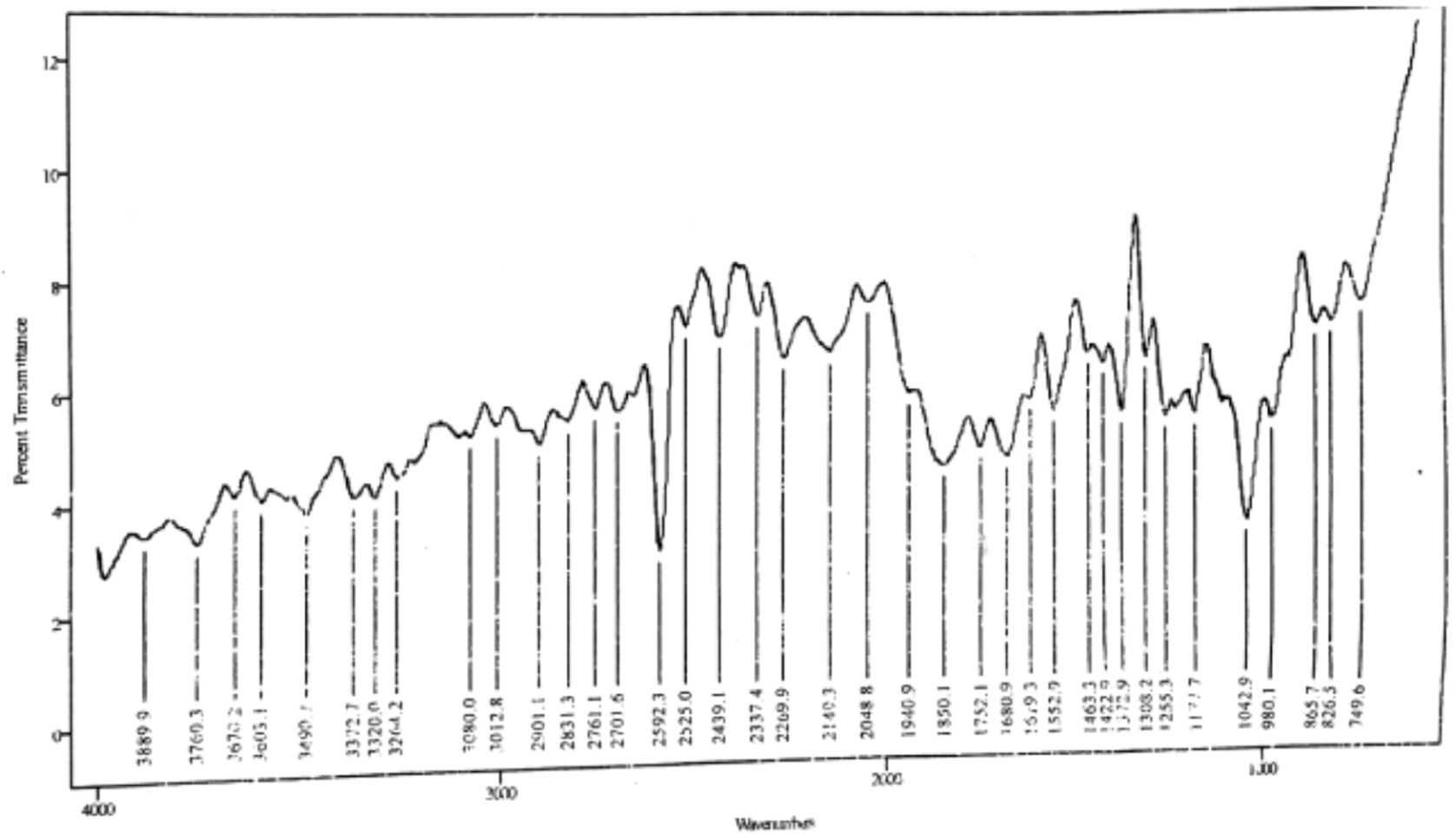

(b) FTIR Spectrum of OPA

Fig. 3 a FTIR Spectrum of OPR. b FTIR Spectrum of OPA

and greater $R^{2}$ value gave the best fit. Table 5 shows that pseudo-second-order kinetic model best describe the adsorption of IBP onto OPAC (Bello et al. 2008). One of the most suitable models for explaining the mechanism of chemisorption is the Elovich equation (Tan et al. 2009). This model assumes that the solid surfaces are actively heterogeneous. 
Table 2 FTIR spectra of raw and acid-activated orange peel (OP) wavenumber $(\mathrm{cm}-1)$

\begin{tabular}{llll}
\hline OPR & OPA & Differences & Band assignment \\
\hline 31,072 & 3490.7 & +383.5 & O-H Stretch \\
2583.2 & 2592.3 & +9.1 & C-H Stretch \\
1777.1 & 1850.1 & +73 & C=O Stretch \\
1551.7 & 1552.9 & +1.2 & C=C Stretch \\
1268.7 & 1372.9 & +104.2 & C-H bending \\
1167.2 & 1042.9 & -124.3 & C-N Stretch \\
820.5 & 865.7 & +45.2 & C-H bending \\
\hline
\end{tabular}

Table 3 Isotherm parameters for IBP adsorption onto OPA at different temperatures

\begin{tabular}{lccc}
\hline Model & Temperature $(K)$ & & \\
\hline Langmuir isotherm & 303 & 313 & 323 \\
$q_{m}$ & 26.50 & 38.60 & 49.30 \\
$K_{L}$ & 5.00 & 1.58 & 1.45 \\
$R_{L}$ & 0.004 & 0.013 & 0.014 \\
$R^{2}$ & 0.970 & 0.993 & 0.917 \\
Freundlich isotherm & & & \\
$K_{f}$ & 20.3 & 25.3 & 59.9 \\
$n$ & 3.10 & 1.50 & 0.90 \\
$R^{2}$ & 0.967 & 0.962 & 0.933 \\
Temkin isotherm & & & \\
$K_{T}$ & 1.37 & 1.80 & 3.10 \\
$b_{T}$ & 65.00 & 40.90 & 30.40 \\
$R^{2}$ & 0.912 & 0.996 & 0.952 \\
$B$ & 3.85 & 8.13 & 13.67 \\
D-R isotherm & & & \\
$q_{m}$ & 21.50 & 26.00 & 41.10 \\
$R^{2}$ & 0.945 & 0.993 & 0.958 \\
$\beta$ & $1 \mathrm{E}-06$ & $3 \mathrm{E}-06$ & 5.00 \\
$E_{a(\mathrm{~kJ} / \mathrm{mol})}$ & 7.07 & 4.08 & \\
\hline
\end{tabular}

Table 4 Adsorption capacities of IBP on various adsorbents
Hypothetically, an increase in the temperature of the solution, leads to a decrease in the surface coverage $(\beta)$, because at higher temperature there is reduction in the available sites for adsorption. Low $R^{2}$ values were obtained for the adsorption process ranging from 0.8433 to 0.9679 . According to Dogan et al., low $R^{2}$ value is an indication of disagreement between the experimental data in Elovich kinetic model. From Table 5, comparing the correlation coefficient values, the manner with which the adsorption process fitted the three kinetic models: pseudo-second-order $>$ pseudo-firstorder $>$ Elovich. A series of elementary steps resulted in the mechanism for the adsorption of ibuprofen. The rate controlling step is possibly that of intraparticle diffusion. This is further confirmed from the plots of $q_{t}$ versus $t^{1 / 2}$ giving a linear plot that does not pass through the origin. The value of the intercept $C$ shows the relationship between the boundary layer thickness and the boundary layer effect (Ozcan et al. 2005). The boundary layer effect is a measure of the bias or affinity of the adsorbent for IBP.

The rate constant $k_{\mathrm{diff}}, C$ and $R^{2}$ are shown in Table 5 . For intraparticle diffusion model, the correlation coefficients $\left(R^{2}\right)$ are between 0.8385 and 0.9682 , which implies that adsorption of IBP onto OPA was intraparticle diffusion model controlled. Figure 5 represents the plot of $q_{t}$ against $t^{1 / 2}$ at various initial concentrations. The plot does not pass through the origin; this is suggesting some level of boundary layer diffusion (Wang and Wang 2007).

\section{Thermodynamic studies}

This study was undertaken to determine the changes in energy that happen in the process. Thermodynamic parameters investigated include: change in entropy $\left(\Delta S^{\circ}\right)$, change in enthalpy $\left(\Delta H^{\mathrm{o}}\right)$, and standard free energy change $\left(\Delta G^{\mathrm{o}}\right)$. The $\Delta H^{\circ}$ and $\Delta S^{\circ}$ values were calculated from the slopes and intercepts (respectively) of the graph of $\ln k_{L}$ against $1 / T$ (inverse of temperature, $T$ ). The negative value of $\Delta \mathrm{H}^{\circ}$ at a particular temperature indicate the exothermic nature of the adsorption process, likewise the positive value of $\Delta S^{\circ}$ confirms an increase in the degree of randomness at the

\begin{tabular}{lcl}
\hline Adsorbent & Adsorptive capacity $\left(\mathrm{mgg}^{-1}\right)$ & References \\
\hline Honeycomb-shaped activated carbon & 16.73 & Dubey et al. (2010) \\
AC from olive waste cake & 9.09 & Baccar et al. (2012) \\
Mesoporous silica SBA-15 & 0.41 & Bui and Choi (2009) \\
Olive waste cake & 12.60 & Baccar et al. (2012) \\
Parthenium hysterophorus & 3.289 & Sandip et al. (2016) \\
Artemisia vulgaris-derived mesoporous honeycomb- & 16.945 & Shashi et al. (2010) \\
shaped activated carbon & & \\
Raspberry derived carbon-tubules & 20.0 & Dubey et.al. (2014) \\
Activated Orange Peel (OPA) & 49.3 & This present work \\
\hline
\end{tabular}


Table 5 Pseudo-first-order, pseudo-second-order Elovich and intraparticle diffusion model parameters for ibuprofen adsorption onto OPA at $30{ }^{\circ} \mathrm{C}$
Fig. 4 Plot of pseudo-secondorder kinetic model at $30^{\circ} \mathrm{C}$ for ibuprofen adsorption onto OPA

\begin{tabular}{|c|c|c|c|c|c|c|}
\hline Kinetic model & Parameters & $10 \mathrm{mg} / \mathrm{L}$ & $20 \mathrm{mg} / \mathrm{L}$ & $30 \mathrm{mg} / \mathrm{L}$ & $40 \mathrm{mg} / \mathrm{L}$ & $50 \mathrm{mg} / \mathrm{L}$ \\
\hline \multicolumn{7}{|c|}{ Pseudo-first-order } \\
\hline & $k_{1}$ & 0.017 & 0.029 & 0.031 & 0.041 & 0.049 \\
\hline & $Q_{e}(\mathrm{cal})(\mathrm{mg} / \mathrm{g})$ & 0.316 & 0.283 & 0.288 & 0.333 & 0.686 \\
\hline & $Q_{e}(\exp )(\mathrm{mg} / \mathrm{g})$ & 4.750 & 9.993 & 13.962 & 19.953 & 24.712 \\
\hline & $R^{2}$ & 0.935 & 0.919 & 0.921 & 0.928 & 0.885 \\
\hline & SSE $(\%)$ & 1.980 & 4.343 & 6.120 & 8.770 & 10.700 \\
\hline \multicolumn{7}{|c|}{ Pseudo-second-order } \\
\hline & $k_{2}$ & 0.311 & 0.441 & 0.408 & 0.418 & 0.233 \\
\hline & $Q_{e}(\mathrm{cal})$ & 4.720 & 9.990 & 13.950 & 19.960 & 24.750 \\
\hline & $Q_{e}(\exp )$ & 4.750 & 9.993 & 13.962 & 19.953 & 24.712 \\
\hline & $R^{2}$ & 0.999 & 1.000 & 1.000 & 1.000 & 1.000 \\
\hline & SSE $(\%)$ & 0.013 & 0.001 & 0.005 & 0.003 & 0.017 \\
\hline \multicolumn{7}{|l|}{ Elovich } \\
\hline & $\alpha$ & $3.37 \mathrm{E}+25$ & $4.503 \mathrm{E}+5$ & $1.44 \mathrm{E}+67$ & $1.76 \mathrm{E}+9$ & $4.48 \mathrm{E}+3$ \\
\hline & $\beta$ & 14.140 & 12.400 & 11.600 & 10.760 & 3.067 \\
\hline & $R^{2}$ & 0.868 & 0.968 & 0.931 & 0.843 & 0.849 \\
\hline \multicolumn{7}{|l|}{ Intraparticle } \\
\hline & $k_{\text {diff }}$ & 0.031 & 0.032 & 0.034 & 0.033 & 0.083 \\
\hline & $C$ & 4.393 & 9.681 & 13.620 & 19.647 & 24.012 \\
\hline & $R^{2}$ & 0.968 & 0.929 & 0.893 & 0.896 & 0.839 \\
\hline
\end{tabular}

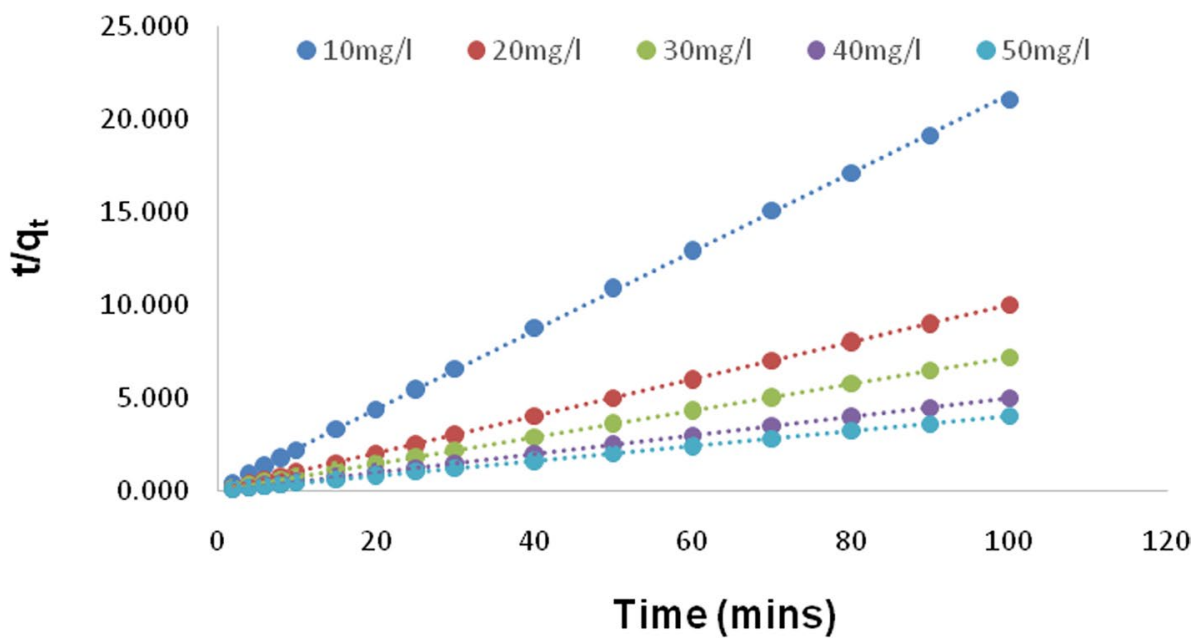

adsorbate/adsorbent interface in the course of the adsorption process. Negative $\Delta G^{\circ}$ values obtained suggest the spontaneity of the process at the temperatures under consideration. Similarly, the energy of activation $E_{a}$ was determined from Arrhenius expressions which indicate the plot of $\ln k_{2}$ against $1 / \mathrm{T}$ for IBP sorption onto OPAC. This result is in consonance with that obtained by Ajemba (2014) for malachite green adsorption by activated clay from aqueous solutions.

Thermodynamic parameters are presented in Table 6. From the table, the negative value of $\Delta \mathrm{H}^{\circ}$ depicts the exothermic nature of the process. $\Delta H^{\circ}$ and $\Delta S^{0}$ values are
$52.76 \mathrm{~kJ} / \mathrm{mol}$ and $60.19 \mathrm{~kJ} / \mathrm{mol} \mathrm{K}$, respectively. It was found that as temperature increases, the $\Delta G^{\circ}$ values decreases; this implies that the force that drives the process decreases at higher temperature, resulting in reduced adsorption. To examine the mechanism governing the sorption process, Arrhenius expression, vis-à-vis activation energy, $E_{a}$, was employed. According to Nollet et al. (2003), for a physiosorption process, the energy of activation value range from 5 to $40 \mathrm{~kJ} / \mathrm{mol}$; while for chemisorption, the value is between 40 and $800 \mathrm{~kJ} / \mathrm{mol}$. For this work, the values of $E_{a}$ obtained fall within that of a physical adsorption i.e. physisoption process. 
Fig. 5 Plot of intraparticle diffusion model of IBP adsorption onto OPA at $30{ }^{\circ} \mathrm{C}$

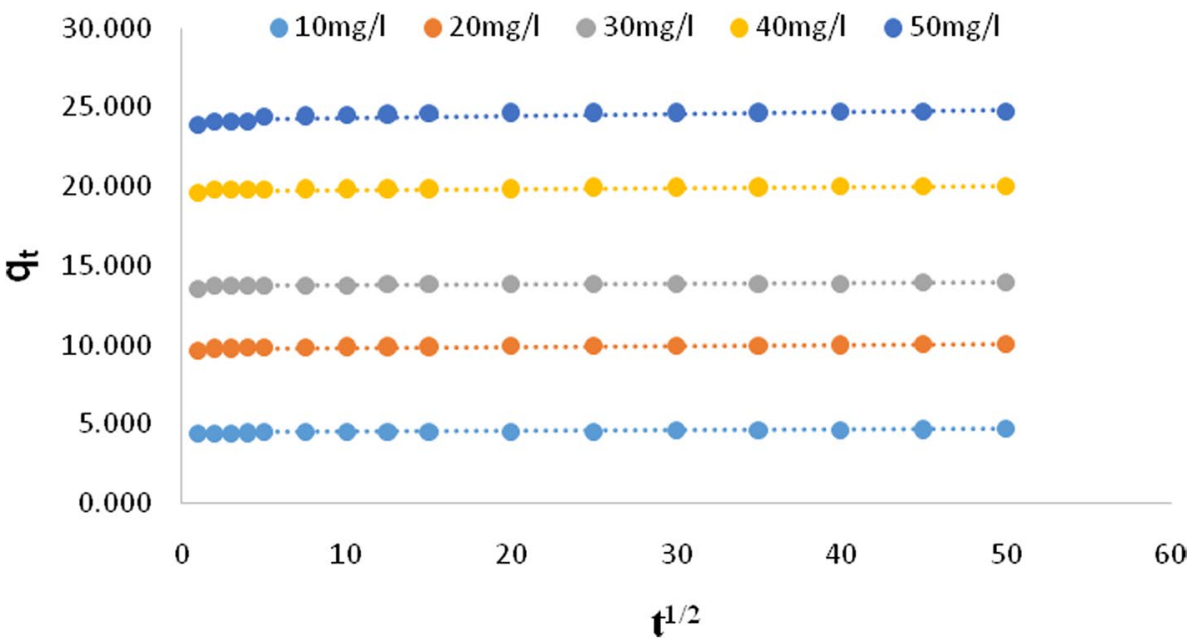

Open Access This article is licensed under a Creative Commons Attribution 4.0 International License, which permits use, sharing, adaptation, distribution and reproduction in any medium or format, as long as you give appropriate credit to the original author(s) and the source, provide a link to the Creative Commons licence, and indicate if changes were made. The images or other third party material in this article are included in the article's Creative Commons licence, unless indicated otherwise in a credit line to the material. If material is not included in the article's Creative Commons licence and your intended use is not permitted by statutory regulation or exceeds the permitted use, you will need to obtain permission directly from the copyright holder. To view a copy of this licence, visit http://creativecommons.org/licenses/by/4.0/.

\section{References}

Aharoni C, Ungarish M (1976) Kinetics of activated chemisorptions. part I: the non-elovichianpart of the isotherm. J Chem Soc Farad Trans 72:265-268

Ahmad MA, Ahmad N, Bello OS (2014a) Adsorptive removal of malachite green dye using durian seed-based activated carbon. Water Air Soil Poll 225:2057. https://doi.org/10.1007/s1127 0-014-2057-z

Ahmad MA, Ahmad N, Bello OS (2014b) Modified durian seed as adsorbent for the removal of methyl red dye from aqueous solutions. Appl Water Sci. https://doi.org/10.1007/s13201-014-02084

Ahmad MA, Afandi NS, Bello OS (2015) Optimization of process variables by response surface methodology for malachite green dye removal using lime peel activated carbon. Appl Water Sci $7: 717-727$

Ajemba RO (2014) Adsorption of malachite green from aqueous solution using activated ntezi clay: optimization, isotherm kinetic studies. Int J Eng Trans C 27(6):839-854

Bello OS, Adeogun AI, Ajaelu JC, Fehintola EO (2008) Adsorption of methylene blue onto activated carbon derived from periwinkle shells: kinetics and equilibrium studies. Chem Ecol 24(4):285-295

Bello OS, Ahmad MA, Ahmad N (2012) Adsorptive features of banana (Musa paradisiaca) stalk-based activated carbon for malachite green dye removal. Chem Ecol 28(2):153-167

Bello OS, Tan TS, Ahmad MA (2011) Adsorption of Remazol brilliant violet-5R reactive dye from aqueous solution by cocoa pod huskbased activated carbon: kinetic, equilibrium and thermodynamic studies. Asia Pac J Chem Eng 7:378-388 
Bui TX, Choi H (2009) Adsorptive removal of selected pharmaceuticals by mesoporous silica SBA-15. J Haz Mater 168:602-608

Buser HR, Poiger T, Müller MD (1999) Occurrence and environmental behavior of the chiral pharmaceutical drug ibuprofen in surface waters and inwastewater. Environ Sci Technol 33:2529-2535

Baccar R, Sarrà M, Bouzid J, Feki M, Blánquez P (2012) Removal of pharmaceutical compounds by activated carbon prepared from agricultural by-product. Chem Eng J 211:310-317

Choi GB, Dong HW, Murphy AJ, Valenzuela DM, Yancopoulos GD, Swanson LW, Anderson DJ (2005) Lhx6 delineates a pathway mediating innate reproductive behaviors from the amygdala to the hypothalamus. Neuron 46:647-660

Ciríaco L, Anjo C, Correia J, Pacheco M, Lopes A (2009) Electrochemical degradation of ibuprofen on $\mathrm{Ti} / \mathrm{Pt} / \mathrm{PbO}_{2}$ and $\mathrm{Si} / \mathrm{BDD}$ electrodes. Electrochim Acta 54:1464-1472

Dordio AV, Candeias AE, Pinto A, da Costa CT, Carvalho AP (2009) Preliminary media screening for application in the removal of clofibric acid, carbamazepine and ibuprofen by SSF-constructed wetlands. Ecol Eng 35:290-302

Dordio A, Carvalho AP, Teixeira DM, Dias CB, Pinto AP (2010) Removal of pharmaceuticals in microcosm constructed wetlands using Typha spp and LECA. Bioresour Technol 101:886-892

Dubinin MM (1960) The potential theory of adsorption of gases and vapors for adsorbents with energetically non-uniform surface. Chem Rev 60:235-266

Daughton CG, Ternes TA (1999) Pharmaceuticals and personal care products in the environment: agents of subtle change? Environ Health Persp 107(6):907-938

Diamanti-Kandarakis E, Bourguignon JP, Giudice LC, Hauser R, Prins GS, Soto AM, Zoeller RT, Gore AC (2009) Endocrine-disrupting chemicals: an endocrine society scientific statement. Endocr Rev 30(4):293-342

Dubinin MM, Radushkevich LV (1947) The equation of the characteristic curve of activated charcoal. Dokl Akad Nauk SSSR 55:327-329

Endocrine Society (2016). Hormones and Health. Retrieved from https ://www.hormone.org/hormones-and-health

Freundlich HM (1906) Over the adsorption in solution. J Phys Chem 57:385-470

Garoma and Matsumoto (2009) Ozonation of aqueous solution containing bisphenol a: Effect of operational parameters. J Haz Mater 167(1-3):1185-1191

Gong R, Zhu S, Zhang D, Chen J, Ni S, Guan R (2008) Adsorption behavior of cationic dyes on citric acid esterifying wheat straw: kinetic andthermodynamic profile. Desal 230:220-228

Gupta VK, Mittal A, Kurup L, Mittal J (2006) Adsorption of a hazardous dye, erythrosine, over hen feathers. J Colloid Interface Sci 304:52-57

Gupta VK, Jain R, Varshney S (2007) Removal of reactofix golden yellow 3 RFN from aqueous solution using wheat husk-an agricultural waste. J Hazard Mater 142:443-448

Gupta VK, Mittal A, Malviya A, Mittal J (2009) Adsorption of carmoisine $A$ from waste water using waste materials-bottom ash and deoiled soya. J Colloid Interface Sci 335:24-33

Ho Y, McKay G (1999a) The sorption of lead (II) ions on peat. Water Res 33:578-584

Hafez ESE, Jainudeen MR, Rosnina Y (2016) Hormones, growth factors, and reproduction. In: Reproduction in farm animals, 7 th edn. Wiley, New York, pp 31-54. https://doi.org/10.1002/9781119265 306.ch3

Ho YS, McKay G (1999b) Pseudo-second order model for sorption processes. Proc Biochem 34:451-465

Lagergren S (1898) ZurTheorie der sogenannten adsorption geloester stoffe. Veternskapsakad Handl 24:1-39

Langmuir I (1918) The adsorption of gases on plane surfaces of glass, mica and platinum. J Am Chem Soc 40:1361-1403
Mittal A, Gupta VK, Malviya A, Mittal J (2008) Process development for the batch and bulk removal and recovery of a hazardous, watersoluble azo dye (metanil yellow) by adsorption over waste materials (bottom ash and de-oiled soya). J Hazard Mater 151:821-832

Méndez-Arriaga F, Torres-Palma R, Pétrier C, Esplugas S, Gimenez J, Pulgarin C (2008) Ultrasonic treatment of water contaminated with ibuprofen. Water Res 42:4243-4248

Manrique J, Martinez F (2007) Solubility of ibuprofen in some ethanol+ water co-solvent mixtures at several temperatures. Lat Am J Pharm 26:344

Nasuha N, Hameed BH, Din ATM (2010) Rejected tea as a potential low-cost adsorbent for the removal of methylene blue. J Hazard Mater 175:126-132

National Institute of Environmental Health Sciences (2019). Endocrine Distruptors. NIEHS Newsletter; Health and Education. https:// www.niehs.nih.gov/health/topics/agents/endocrine

Nollet H, Roels M, Lutgen P, Meeren PVD, Verstraete W (2003) Removal of PCBs from wastewater using fly ash. Chem Eco 53:655-665

Ozcan AS, Erdem B, Ozcan A (2005) Adsorption of acid Blue 193 from aqueous solutions onto BTMA activated bentonite. Colloid Surf A Physicochem Eng Aspect 266:73-81

Propper CR (2005) The study of endocrine-disrupting compounds: past approaches and new directions. Integr Comp Biol 45(1):194-200

Santos J, Aparicio I, Alonso E (2007) Occurrence and risk assessment ofpharmaceutically active compounds in wastewater treatment plants. a casestudy: seville city (Spain). Environ Int 33:596-601

Sebastine IM, Wakeman RJ (2003) Consumption and environmental hazards of pharmaceutical substances in the UK. Proc Safety Environ Protec 81(4):229-235

Shashi PD, Amarendra DD, Mika S, Krishna G (2010) Artemisia vulgaris-derived mesoporous honeycomb-shaped activated carbon for ibuprofen adsorption. Chem Eng J 165(2010):537-544

Singh KP, Singh AK, Singh UV, Verma P (2012) Optimizing removal of ibuprofen from water by magnetic nanocomposite using boxbehnken design. Environ Sci Pollut Res 19:724-738

Swedenborg E, Ruegg J, Makela S, Pongratz I (2009) Endocrine disruptive chemicals: mechanisms of action and involvement in metabolic disorders. J Mol Endocrinol 43(1):1-10

Tan IAW, Ahmad AL, Hameed BH (2009) Fixed-bed adsorption performance of oil palm shell-based activated carbon for removal of 2,4,6-trichlorophenol. Bioresou Technol 100(3):1494-1496

Temkin M, Pyzhev V (1940) Kinetics of ammonia synthesis on promoted iron catalysts. Acta physiochim URSS 12(3):217-222

Tunç Ö, Tanac H, Aksu Z (2009) Potential use of cotton plant wastes for the removal of remazol black B reactive dye. J Hazard Mater 163:187-198

Wang L, Wang A (2007) Adsorption characteristics of Congo red onto the Chitosan / montmorillonite nanocomposite. J Hazard Mater 147:979-985

Weber WJ, Morris JC (1962) Kinetics of adsorption on carbon from solution. J Sanit Eng Div ASCE 89:31-59

Zhang Y, Pan B (2014) Modeling batch and column phosphate removal byhydrated ferric oxide-based nanocomposite using response surface methodology and artificial neural network. Chem Eng J 249:111-120

Publisher's Note Springer Nature remains neutral with regard to jurisdictional claims in published maps and institutional affiliations. 